\title{
GENETIC SIGNIFICANCE OF THE IRONSTONE FACIES OF THE MAASTRICHTIAN PATTI FORMATION, BIDA BASIN, NIGERIA: INSIGHTS FROM CHEMISTRY AND MINERALOGY
}

Olusola J. Ojo ${ }^{1}$, Toba E. Bamidele ${ }^{2}$, Idris Kelani ${ }^{2}{ }^{1}$ Department of Geology, Federal University Oye - Ekiti, P.M.B. 373, Oye-Ekiti, Nigeria (solafoluk@yahoo.com)

2 Department of Geology and Mineral Sciences, University of Ilorin,P.M.B. 1515, Nigeria

\section{Introduction}

The Bida Basin (also known as Nupe Basin), is an oval shaped structural intracratonic sedimentary feature, elongated along northwest-southeast direction and perpendicular to the main axis of the Benue Trough (Fig. 1). The Bida basin is an area of local subsidence formed during the Campanian-Maastrichtian age, during which the South Atlantic-Tethys seaway was probably routed through the Basin (Ojo and Ajakaiye, 1976). Stratigraphic framework in this basin has been along the geographic subdivision of the basin into north and south Bida basins. In the southern Bida basin, the main stratigraphic units are Campanian - Maastrichtian Lokoja Formation (conglomerate, sandstone), Maastrichtian Patti Formation (sandstone, shale, claystone), and Agbaja Formation (ironstone). Ojo and Akande (2009) described the shale-clay member of the Patti Formation as comprising of rhythmically bedded shale, ironstone and claystones and interpreted to have been deposited largely in relatively quiet shallow marine environment. The ironstone unit of the shale-clay member of the Patti Formation is investigated in this study.

\section{Objectives}

i) investigate facies relationships in the Patti Formation ironstones (ii) evaluate their petrographic and mineralogical composition (iii) determine the geochemical composition and (iv) use the above information to interpret the origin and construct a genetic model for the ironstones. 


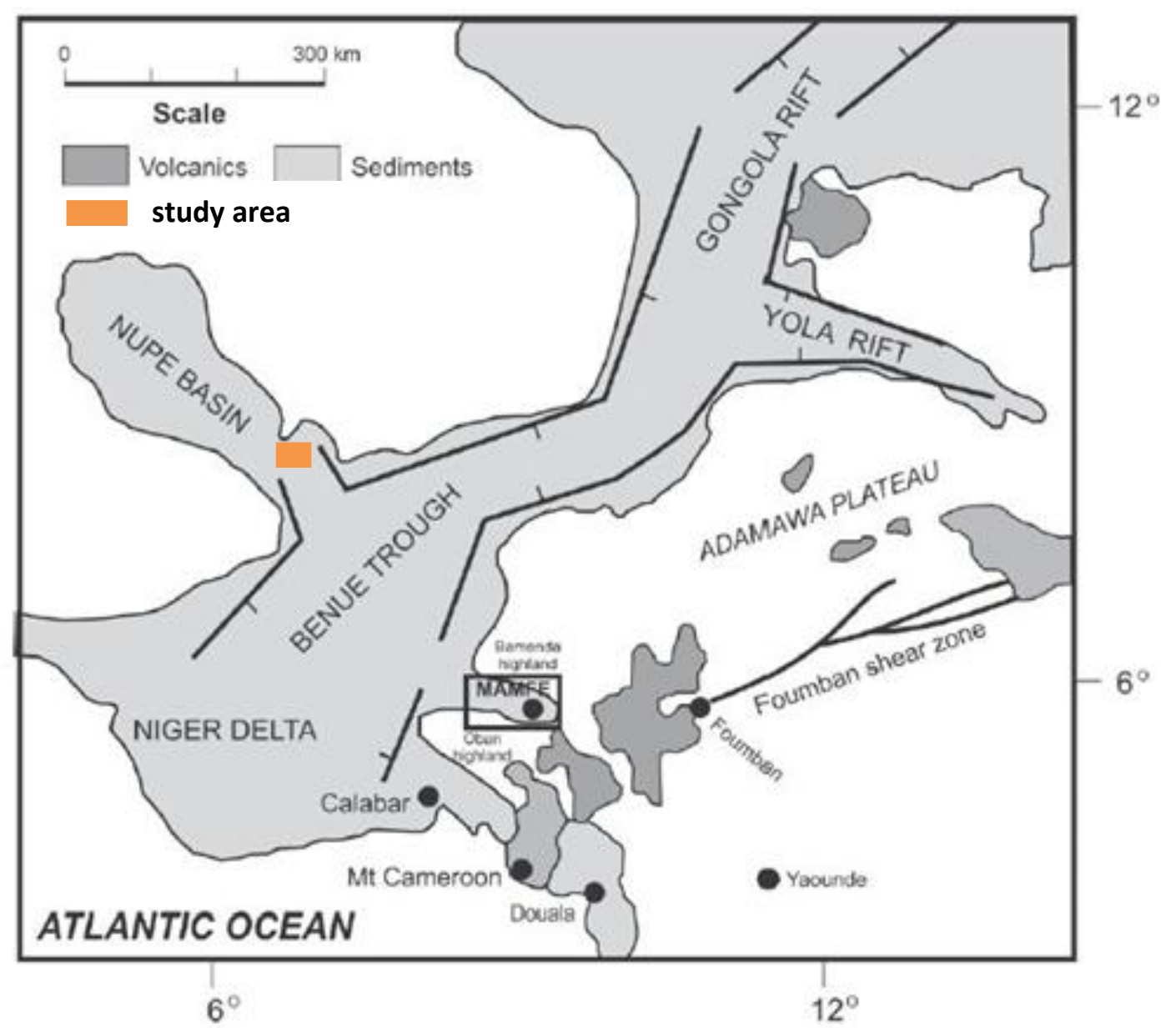

Fig. 1. Geological map of Nigerian and location of the study area

\section{Field Work, Sampling and Analytical Methods}

Two sections were loggednear Lokoja at the confluence of rivers Niger and Benue Nigeria (Fig. 2). Samples were selected from each different lithofacies of the ironstone for thin and polished sections for mineralogic studies and petrofacies classification. Mineral composition was obtained from X-Ray Diffraction. For bulk elemental composition; Major Oxides, Trace Elements (TE) and Rare Earth Elements (RRE) both X-ray Fluorescence (XRF) and Aqua regia ultra-trace Inductively Coupled Plasma Mass Spectroscopy (ICP-MS) analysis were carried out. 

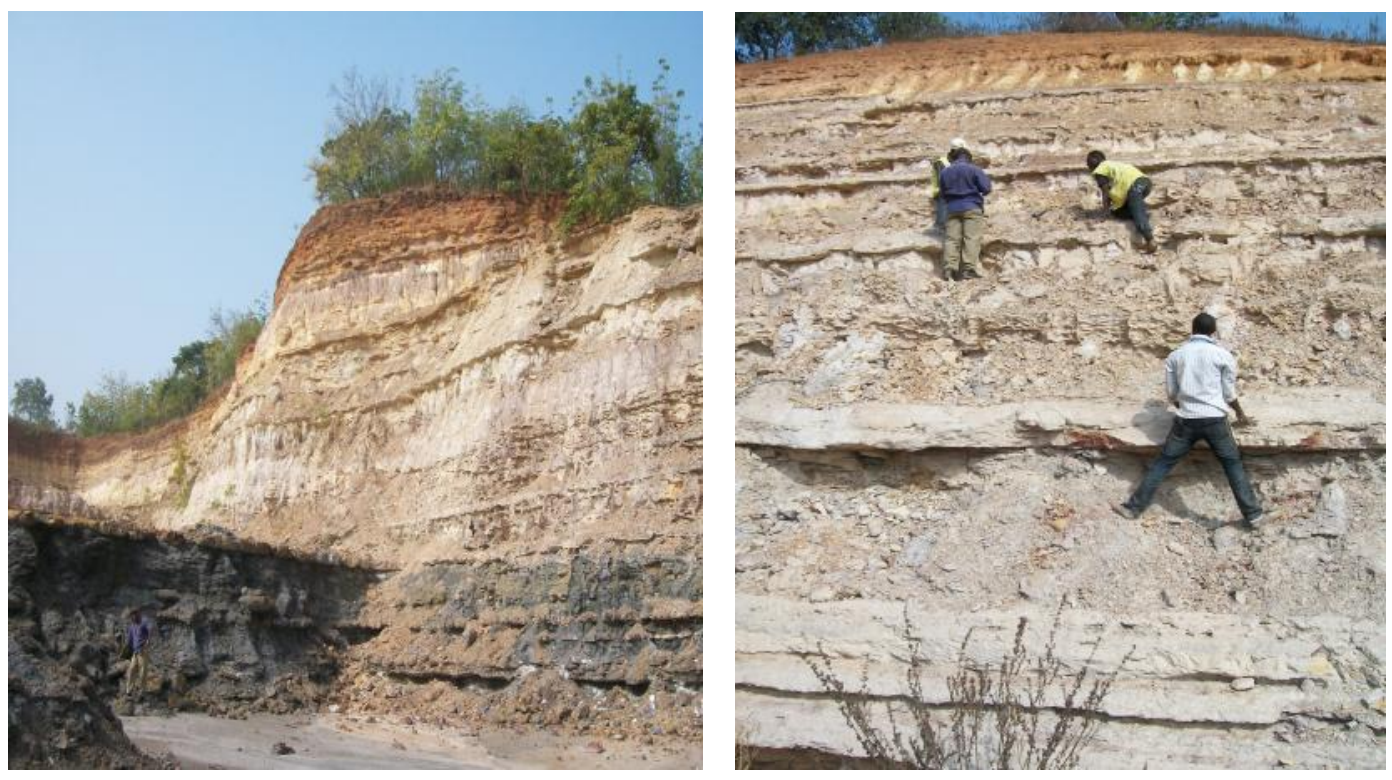

Fig. 2. Quarry face and road cut exposures of the investigated sediments at Ahoko and Geheku

\section{Results}

\subsection{Facies Charactersistics}

\section{Horizontal Laminated and Fossiliferous Ironstone Facies}

This facies of ironstone occur at the basal part of the sections. They are characteristically poorly to distinctly laminated. The laminations are parallel to wavy in places. A typical feature of this facies is their fossiliferous nature. This unit is about 0.5 meter thick (Fig. 3A \&B). This facies is associated with well laminated dark to grayish shales that are rich in organic matter.

\section{Flattened Spheroidal Ironstone Facies}

This typically develops spheroidal concretionary structures which are of varying size. The small flattened concretions concretionary ironstone with poorly developed concretions are generally smaller than $0.1 \times 0.1 \mathrm{~m}$ in dimension. The large flattened concretions concretionary have average dimension of $0.35 \times 0.2 \mathrm{~m}$ (Fig. 3C). Close examination of the pisolites shows that some have concretion with unconsolidated core enclosed by concentric cortex of sideritic bands. The core retains the primarily deposited sediment which has been diagenetically replaced by iron precipitates. The primary sediments retained in the core of this type of concretion are fine sand, silt and clay and this is a pointer to the selective iron compound induration or enrichment of a 
fine sand or silt layer (Fig. 8). Some other concretion is made up of consolidated and well lithified core enclosed by concentric or roughly concentric cortexes of sideritic layers.

\section{Bioturbated Ironstone facies}

This facies of ironstone lacks internal organisation but is rich in burrows of thalassinoides and ophiomorpha which are now filled with ferruginized clayey to silty particles (Figs. 3D \&4). The thickness this ironstone bed in the Ahoko quarry and Geheku sections is about $0.2 \mathrm{~m}$. It is unique, infrequent and restricted to the middle part of the section.
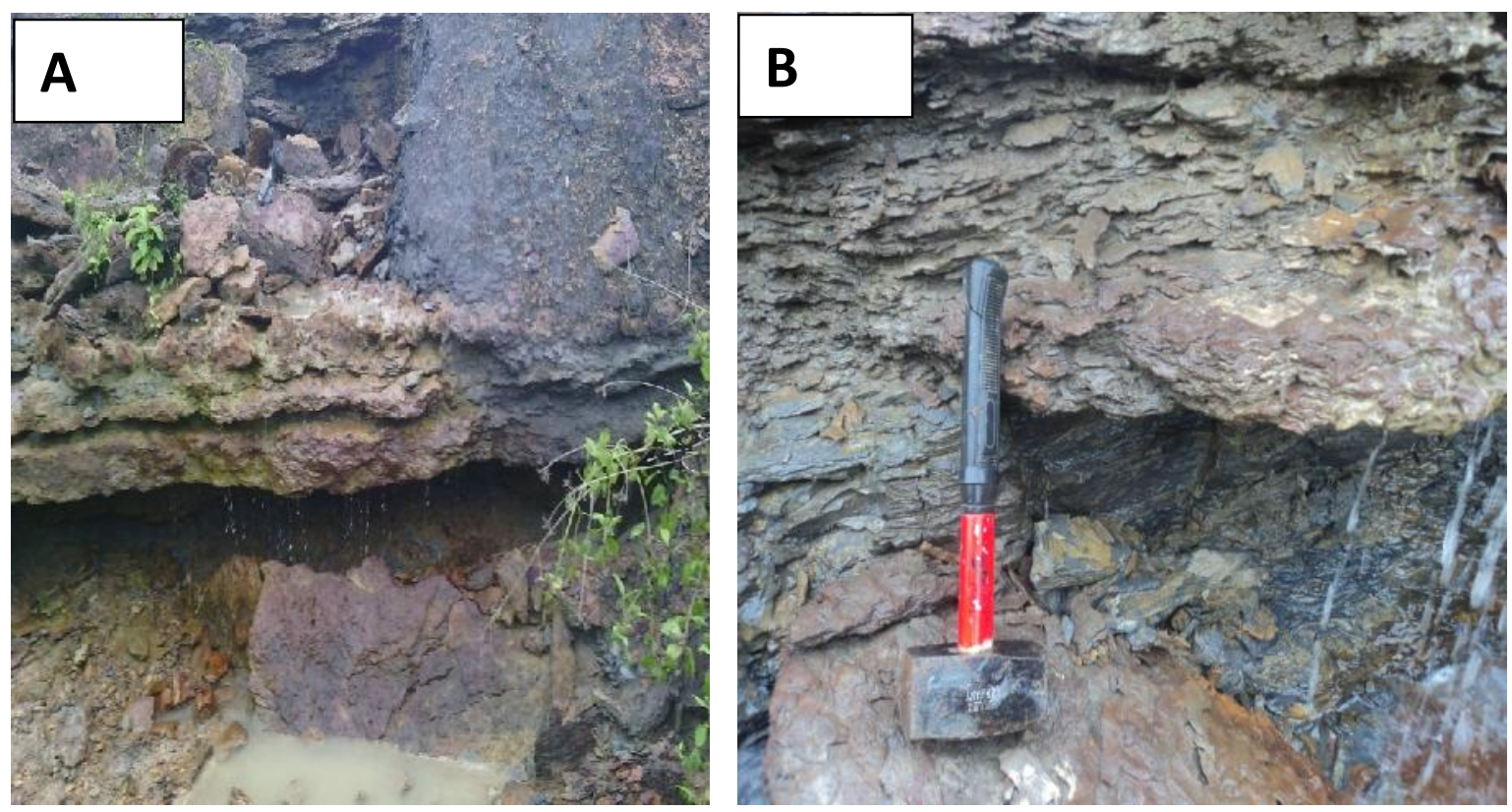

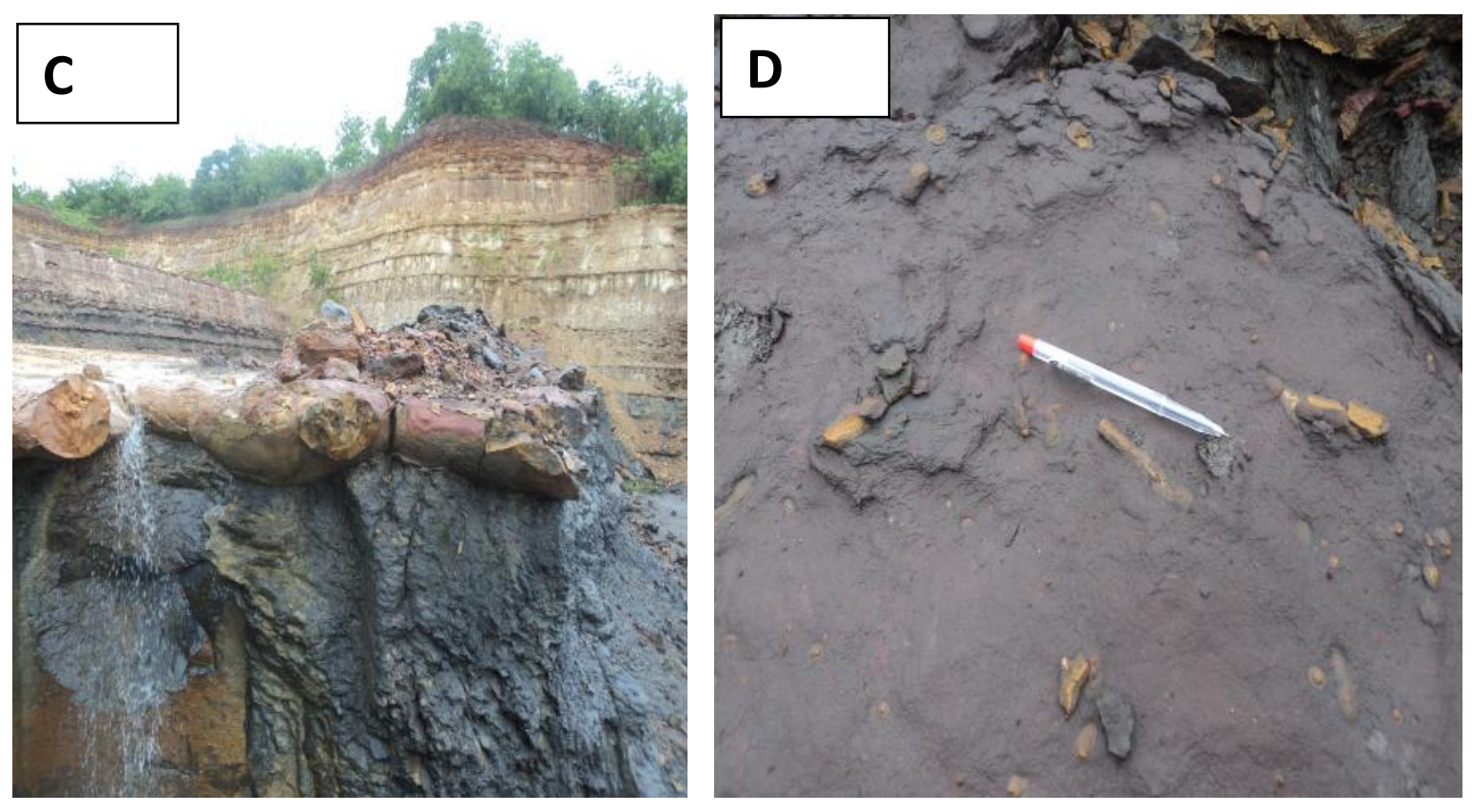

Figure 3.A \&B: Laminated fossiliferous ironstone, C: Spheroidal lithofacies D: Bioturbated massive lithofacies with halassinoides burrows.

\subsection{Mineralogy}

The X-ray diffraction analysis of the samples aided more accurate identification of minerals in the studied ironstone samples and reveal the dominance of siderite $\left(\mathrm{FeCO}_{3}\right)$, quartz $\left(\mathrm{SiO}_{2}\right)$, hematite $\left(\mathrm{Fe}_{2} \mathrm{O}_{3}\right)$, calcite $\left(\mathrm{CaCO}_{3}\right)$, anatase $\left(\mathrm{TiO}_{2}\right)$, illite $\left\{\left[\mathrm{K} 0.6\left(\mathrm{H}_{3} \mathrm{O}\right)_{0.4}\right] \mathrm{Al}_{1.3} \mathrm{Mg} 0.3 \mathrm{Fe}_{2}+\right.$ $0.1 \mathrm{Si}_{3.5} \mathrm{O}_{10}(\mathrm{OH})_{2} \cdot\left(\mathrm{H}_{2} \mathrm{O}\right)$ \}, Ilmenite, $\left(\mathrm{FeTiO}_{2}\right)$ and kaolinite $\left(\mathrm{Al}_{2} \mathrm{Si}_{2} \mathrm{O}_{5}(\mathrm{OH})_{4}\right)$ (Figs.4 and 5) 


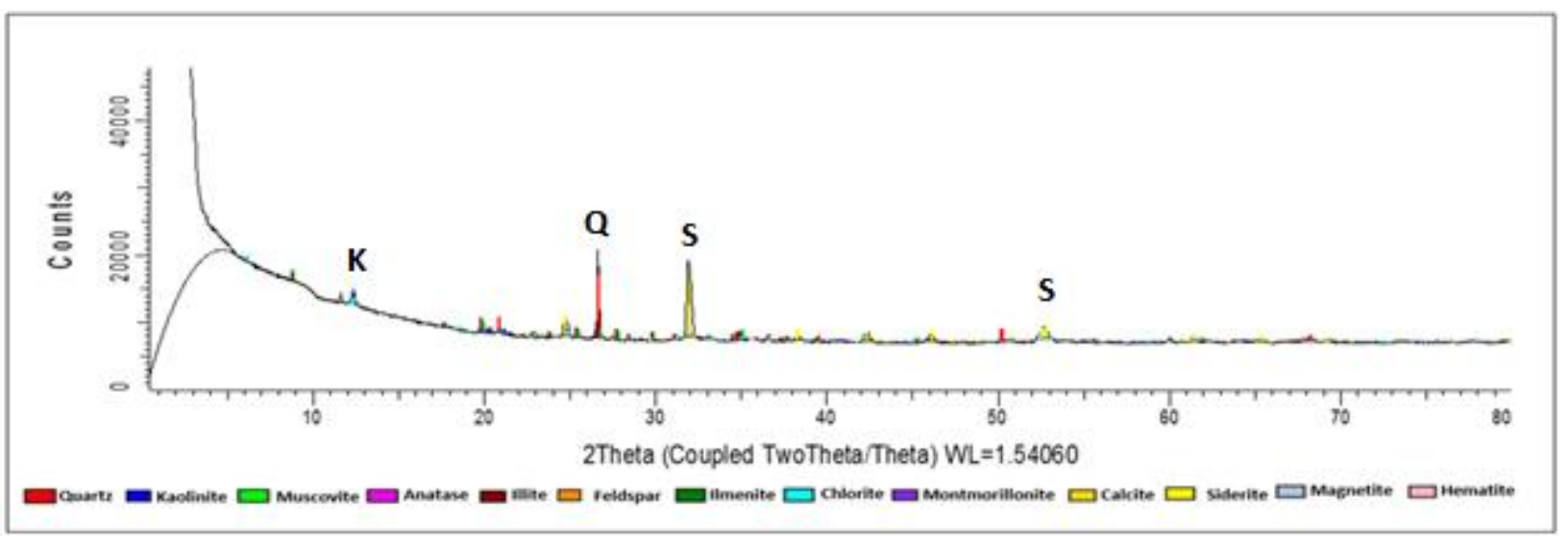

Fig 4A: XRD diffractogram of sample BGH 1E showing peaks for K- Kaolinite, S-Siderite and Q-Quartz.

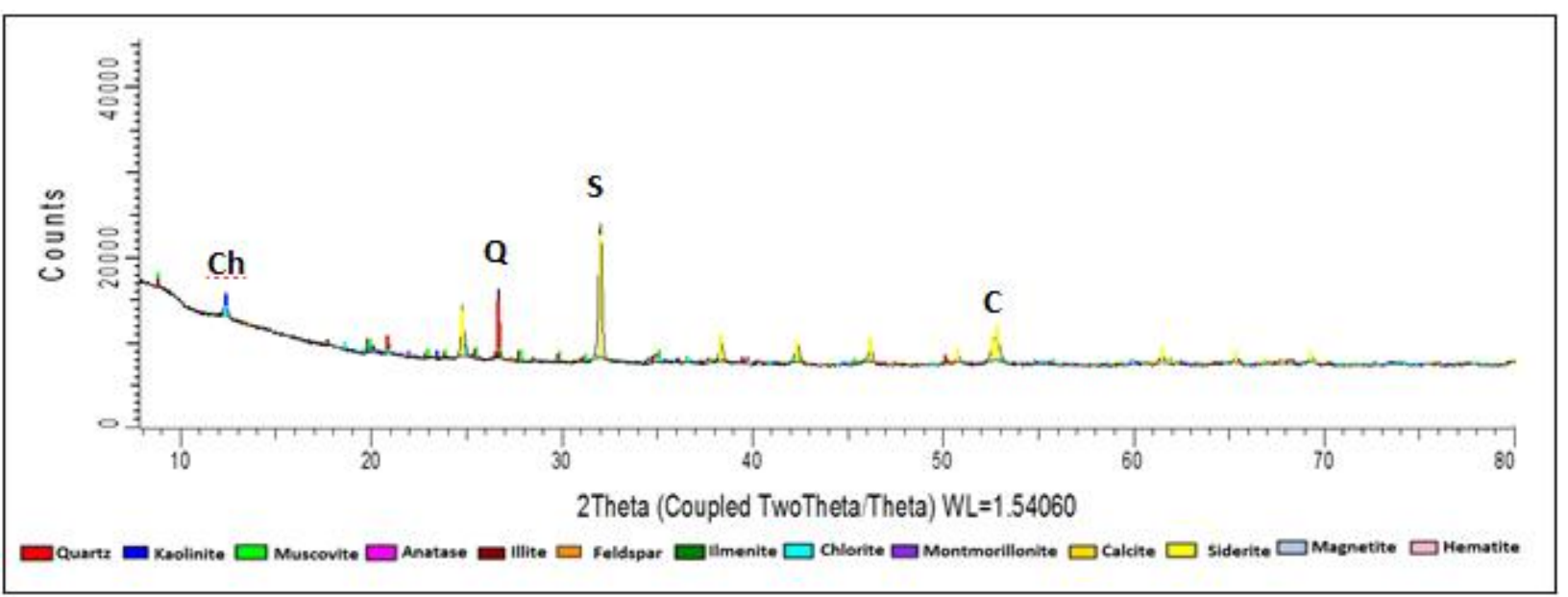

Fig 4B: XRD diffractogram of sample JAH 1B showing peaks for Ch-Chlorite, Q-Quartz, SSiderite and C-Calcite 


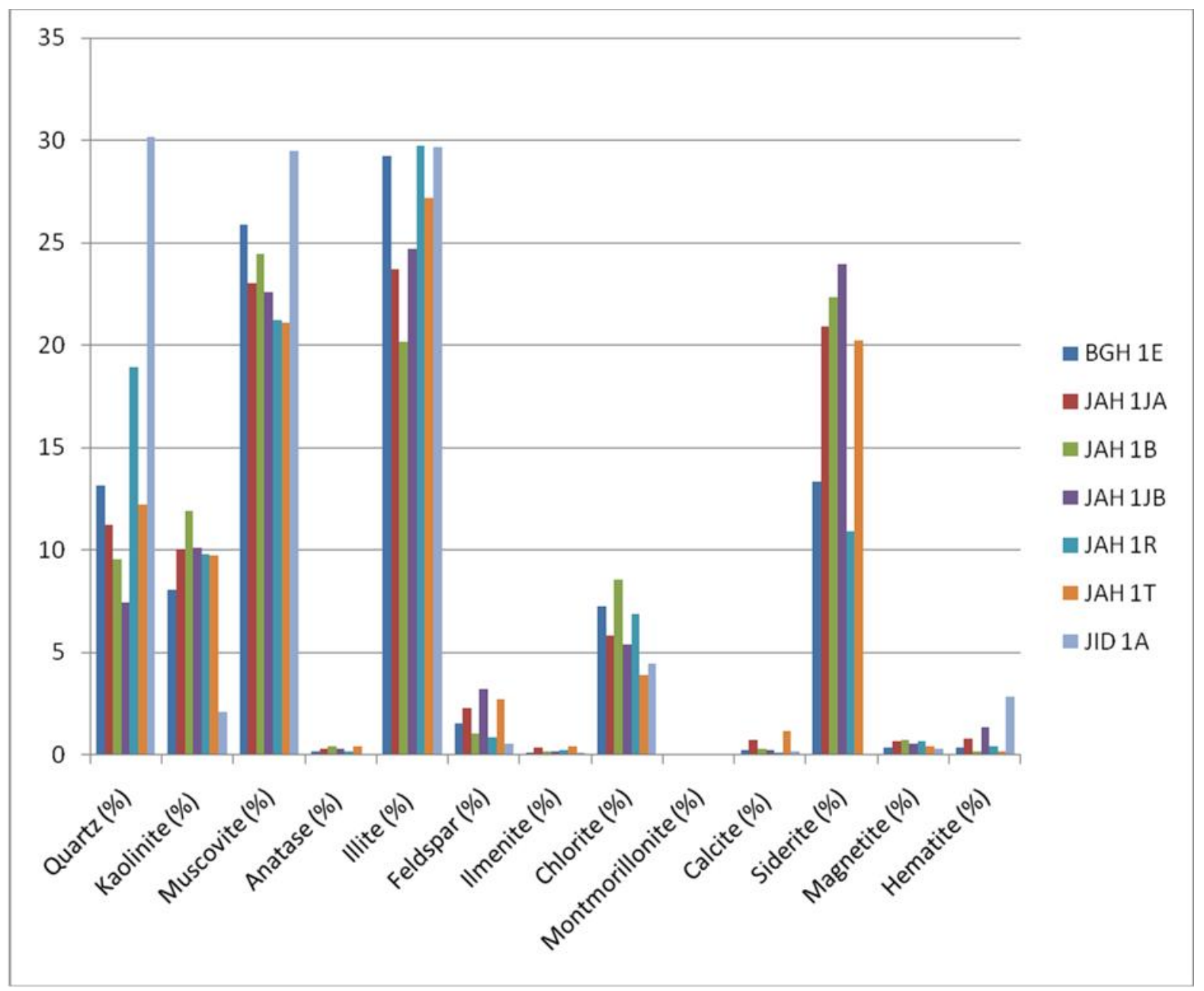

Fig. 5: Relative abundance of minerals in the Patti Formation ironstone samples.

\subsection{Geochemical Data}

The obtained values of major, trace and rare earth elements contents of the ironstones investigated were presented in figure 6. The ironstones consist of $\mathrm{SiO}_{2}, \mathrm{Fe}_{2} \mathrm{O}_{3}$ and $\mathrm{Al}_{2} \mathrm{O}_{3}$ which are the most enriched oxides and make up to $70 \%$ of the oxides in all the ironstone samples as a reflection of the predominance of siderite, hematite, clay minerals, and quartz in the ironstone samples. 


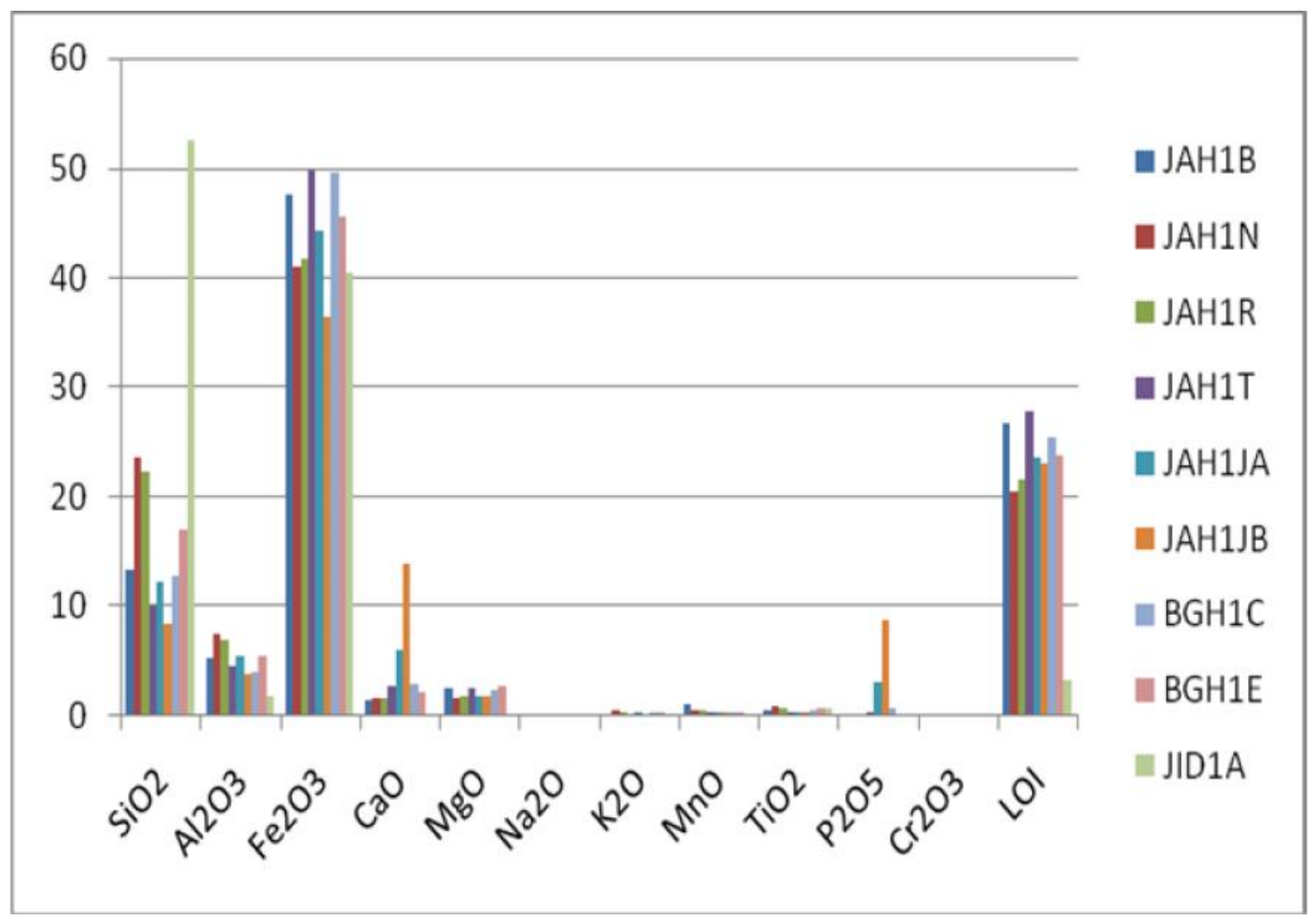

Fig. 6 Major oxide distribution in the ironstones 


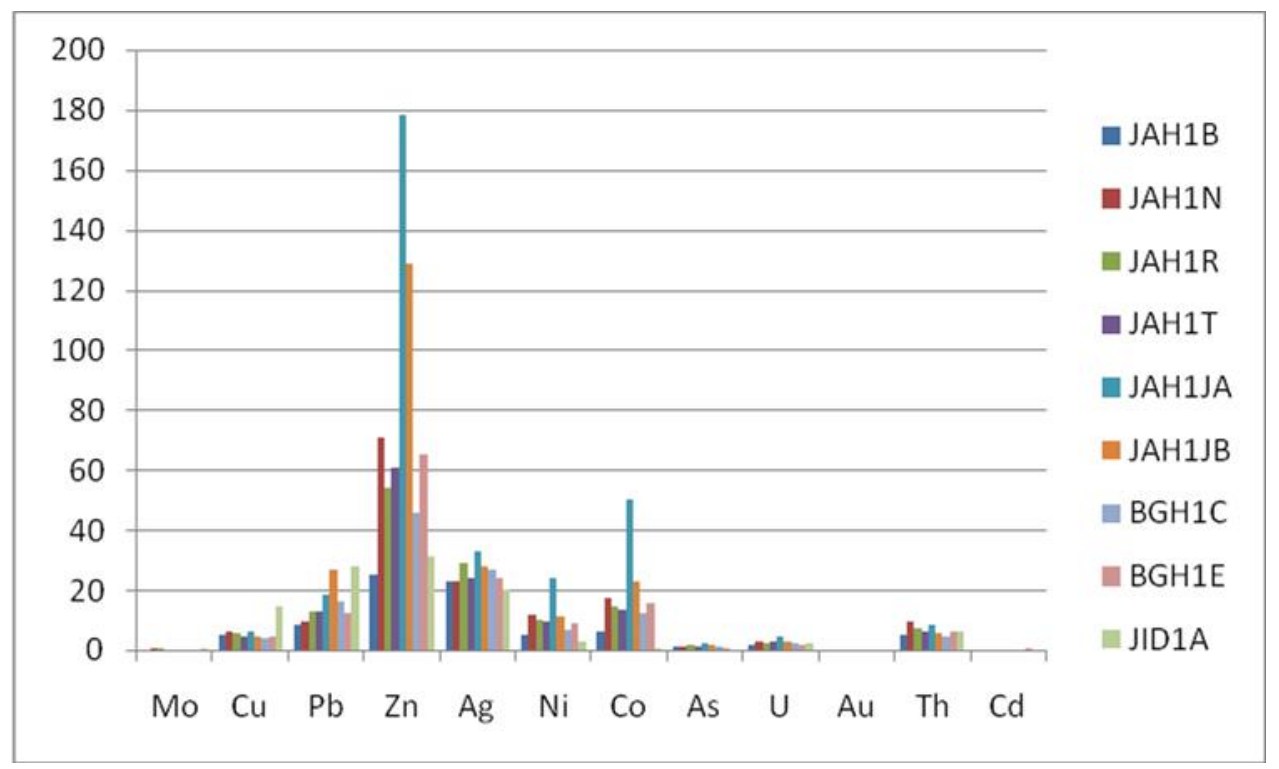

Fig. 7 Relative abudance of the trace trace elements

There is a sharp contrast in the chemical composition of the parallel laminated ironstone facies and others. $\mathrm{CaO}, \mathrm{MgO}$ and $\mathrm{P} 2 \mathrm{O} 5$ are relatively high in the laminated facies but depleted in $\mathrm{SiO} 2$. Concentration of trace elements such as $\mathrm{Zn}, \mathrm{Pb}$ and $\mathrm{Sr}$ is also relatively high. The reverse is the case in the other lithofacies of the ironstones.

\section{Discussion}

\subsection{Diagenesis}

The diagenetic process began very shortly after the sediments are deposited (Fig. 8). The water between the sediment intergranular spaces has the initial composition of sea water, but that changes with burial. The iron also become more soluble and is leached out of the minerals. The dissolved mineral matter (mainly calcium, iron, and carbonate) were trapped in sites within the sediment where they are less soluble and precipitated out either as cement between the grains, bedding planes and fracture fillings in the shale or as replacement in the clay sediment which are essentially kaolinite. 

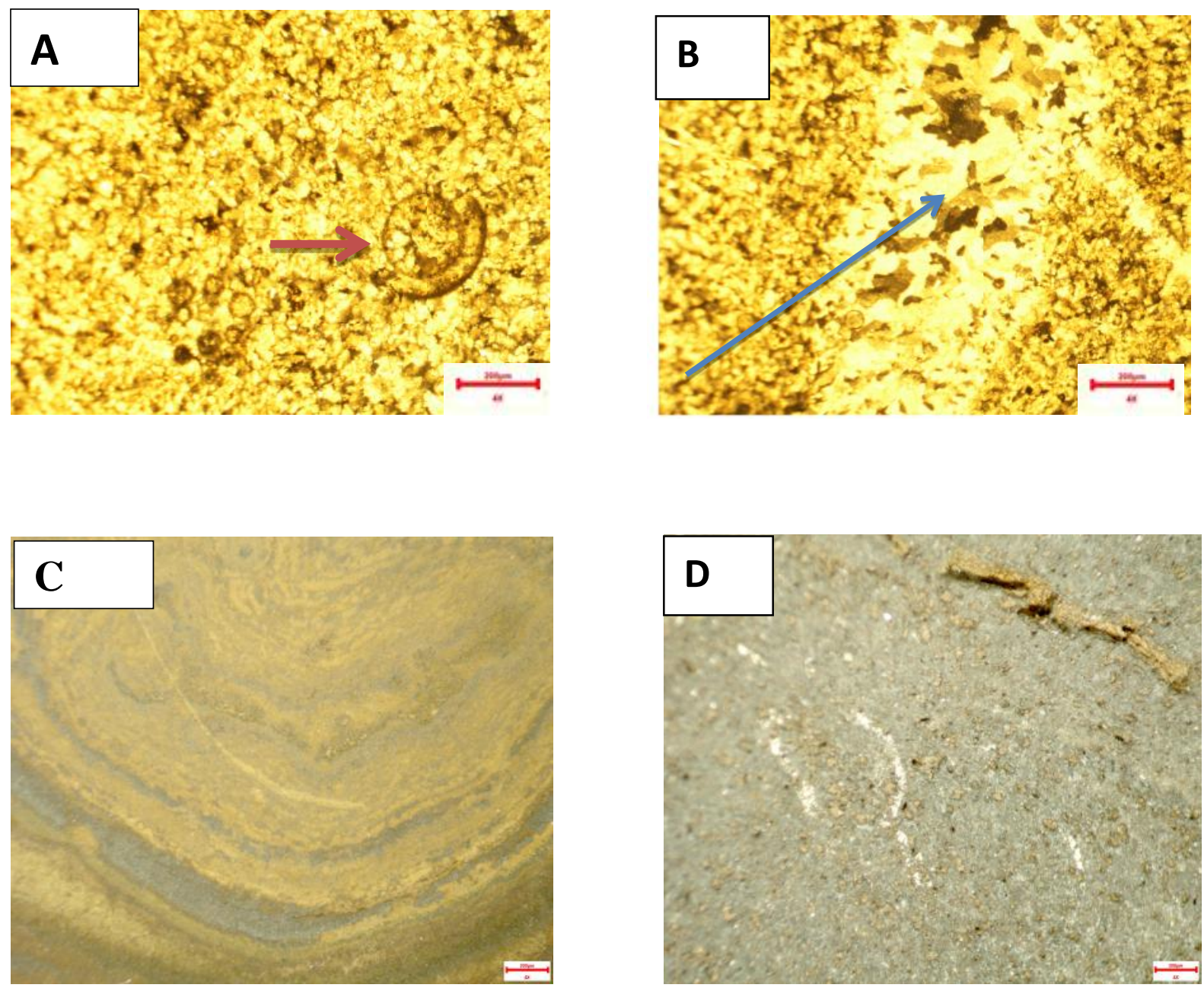

Fig.8A: Sideritized bivalve shell in the laminated fossiliferous ironstone facies; B: Bioturbated facies showing recrystallized burrow: C: Polished section of Spheroidal facies. Note different stages of induration with iron. Dark band representing total replacement of the clay precursor: D: Ferruginized shale with groundmass selectively replaced by iron oxide minerals. Note the relics of the gastropod. 


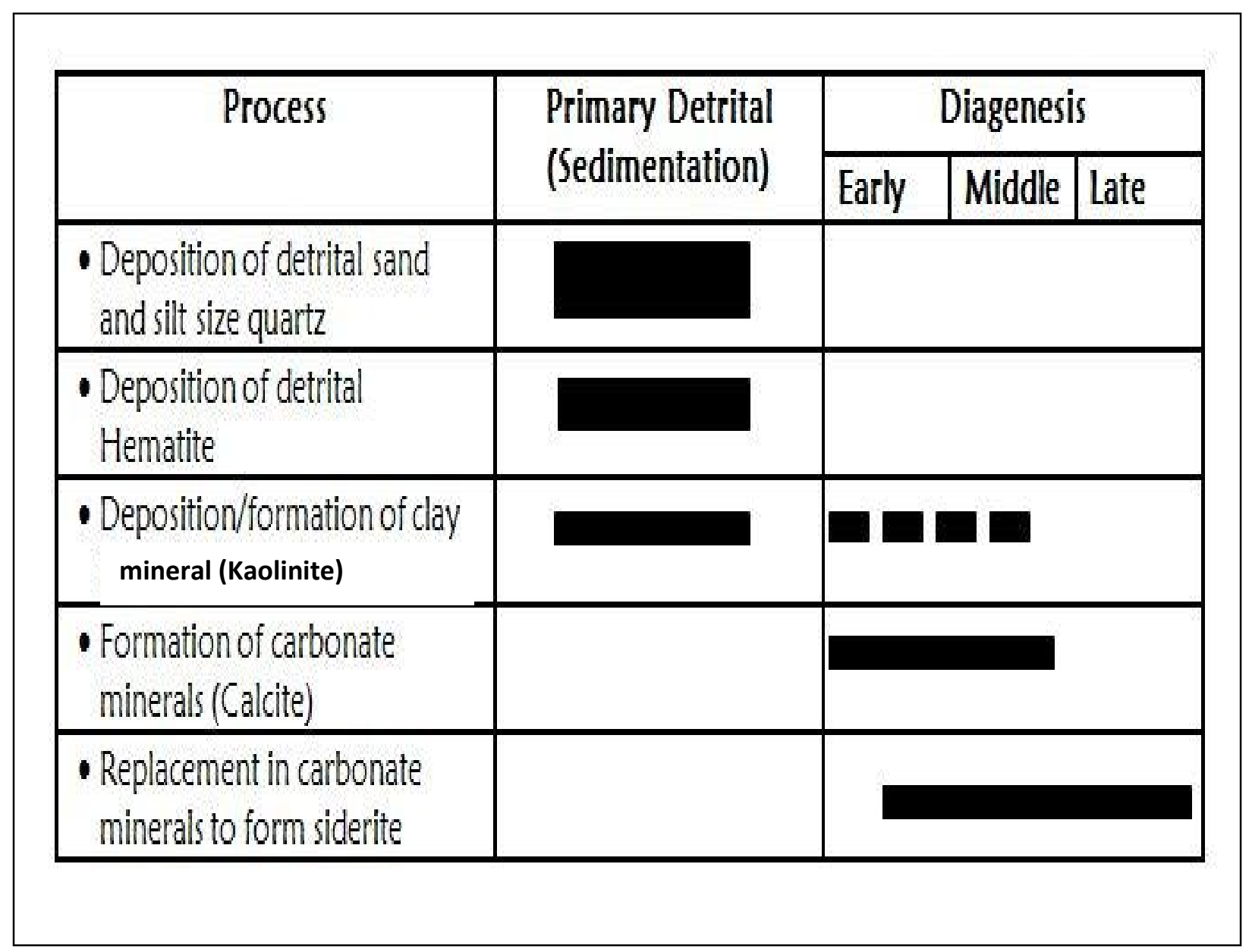

Fig. 9. Paragenetic sequence in the ironstones

\subsection{Genesis and Depositional Environments}

According to (Mücke, 2006) fine grained sediments containing organic matter are decomposed resulting in highly reducing anoxic environment in which abundant siderite are formed. Reduction of iron therefore demands equivalent oxidation of organic matter. Both ferrous iron and carbon dioxide are thus produced together. Geochemical proxies like the discriminating binary plot of $\mathrm{Na}$ against $\mathrm{Mg}$ shows most of the Patti samples plotted in the shallow marine field except sample JID 1A (Fig. 10). Full marine is most likely to have been established at the lower part of the investigated section where the laminated facies is relatively high in $\mathrm{MgO}, \mathrm{P}_{2} \mathrm{O}_{5}$ and $\mathrm{CaO}$. Mineralogical and geochemical evidences show that the investigated ironstones which are essentially sideritic (Fig. 11) falls in the carbonate zone with little contribution of silicate from the oxide zone. Field evidences like preserved gastropod and pelecypod shells which are 
essentially marine faunal and LOI (wt \%) are all pointers to deposition of the clay ironstones of Patti Formation in shallow marine environment with prevailing reducing condition.

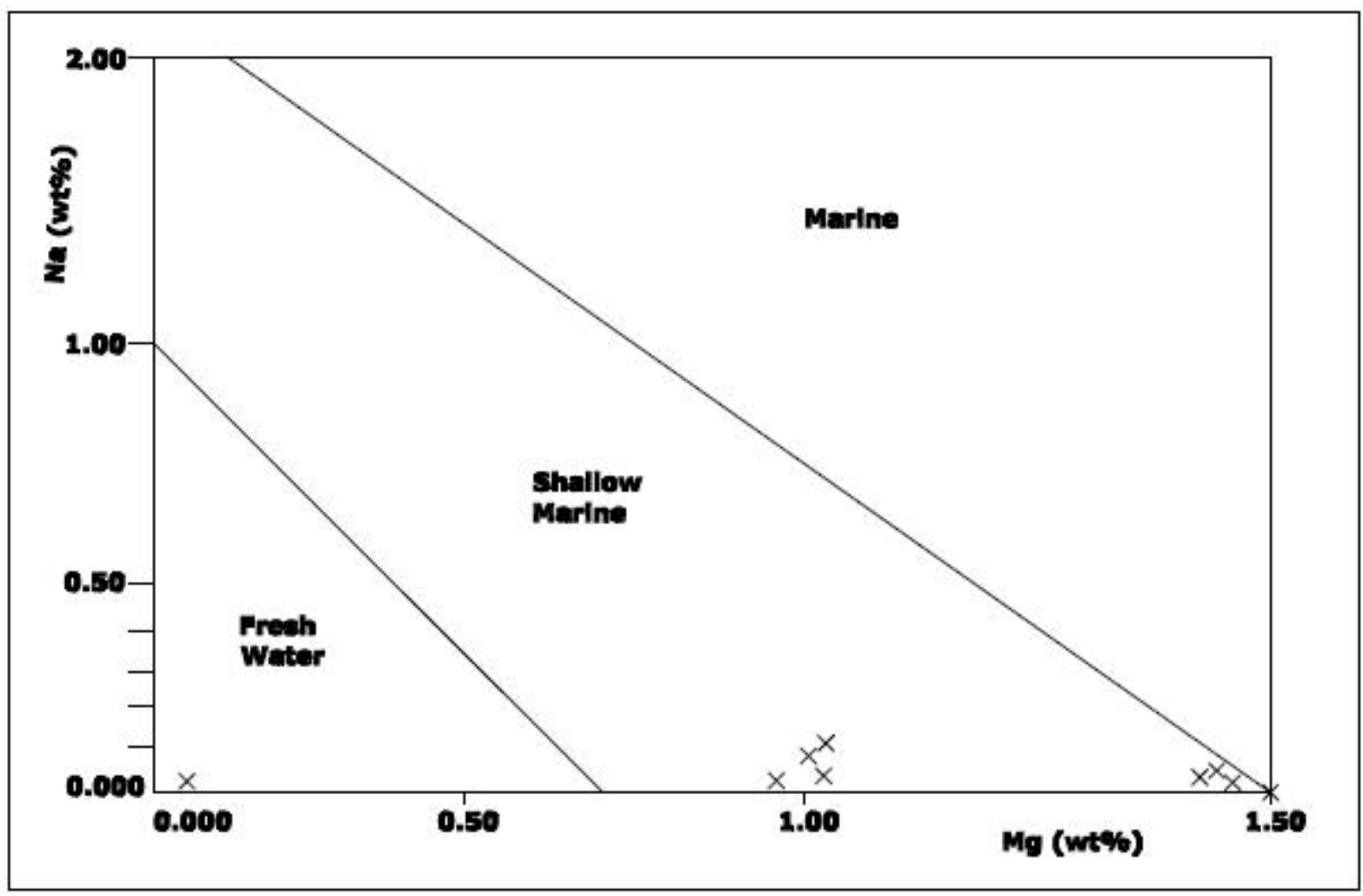

Fig. 10: Discriminative binary plot of $\mathrm{Na}$ against $\mathrm{Mg}$ after Nicholson (1992) showing most samples within shallow marine field, only one sample (JID 1A) plotted in the fresh water field. 


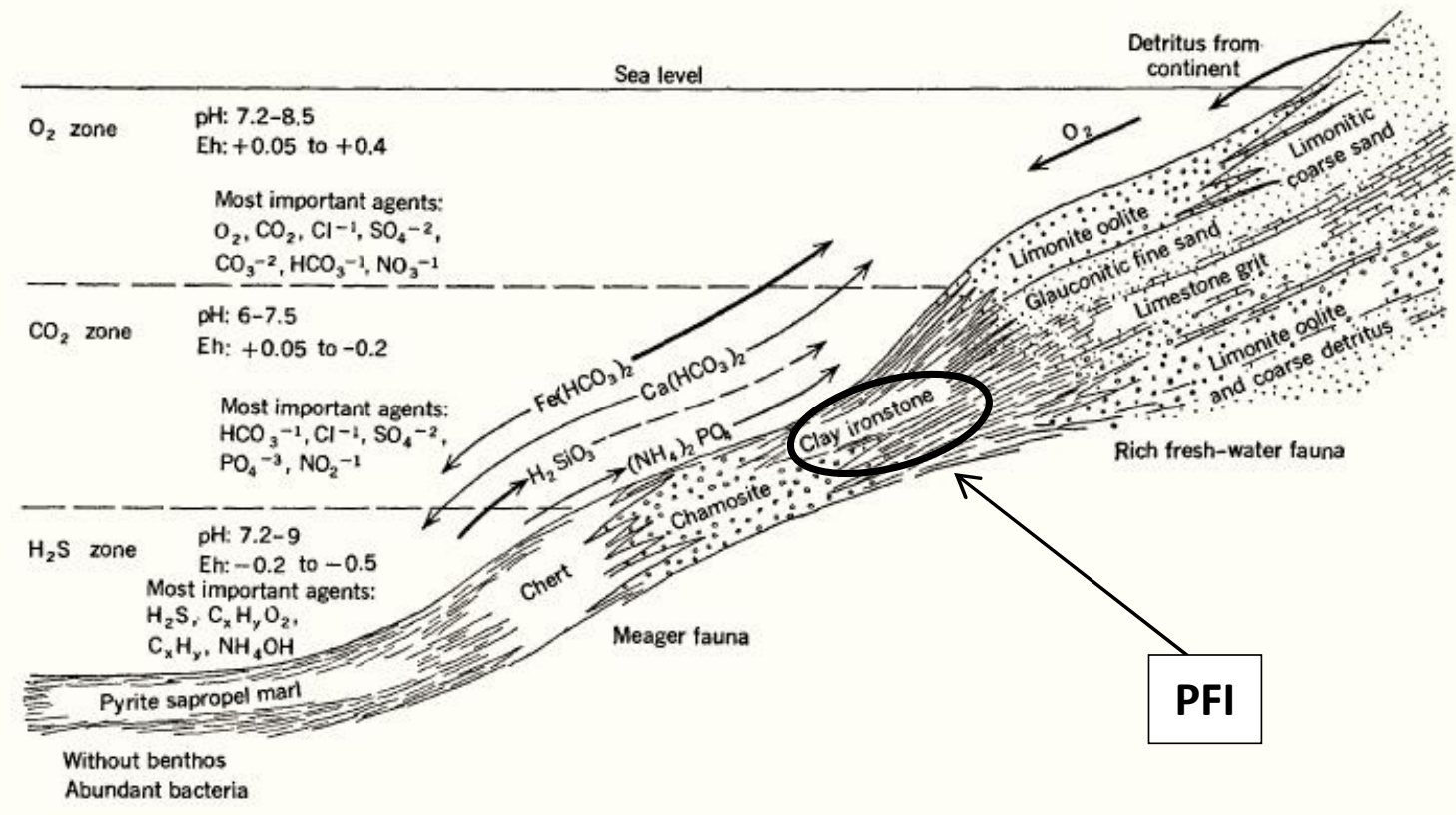

Fig. 11: Schematic section of the relationships between ironstone facies and physicochemical conditions ( Pettijohn, 1975)

\subsection{Genetic model for the origin of Patti Formation Ironstones}

Available data in this study indicates possibility that most of the iron were deposited with the primary sediment load and they were probably sourced from the adjacent Lower-Proterozoic to Precambrian basement complex. Intense weathering lead to release of free iron. The iron oxide minerals were precipitated mainly from diagenetic modifications. Geologic, chemical, and mineralogical considerations pointed to precipitation, diagenetic replacement and neoformation for the bulk of the siderite in the ironstones under reducing condition. From the geochemical evidences, the hydrothermal precipitation is excluded due to the relatively low metal content of the studied ironstone in $\mathrm{Cu}, \mathrm{Pb}$, and $\mathrm{Zn}$ (Gloaguen et al., 2007). The lack of significant correlation of $\mathrm{Fe}$ with $\mathrm{As}, \mathrm{Cu}$, and $\mathrm{Zn}$ elements may also exclude the hydrothermal influences (Lottermoser and Ashley, 1996; Ashley et al., 1998). 


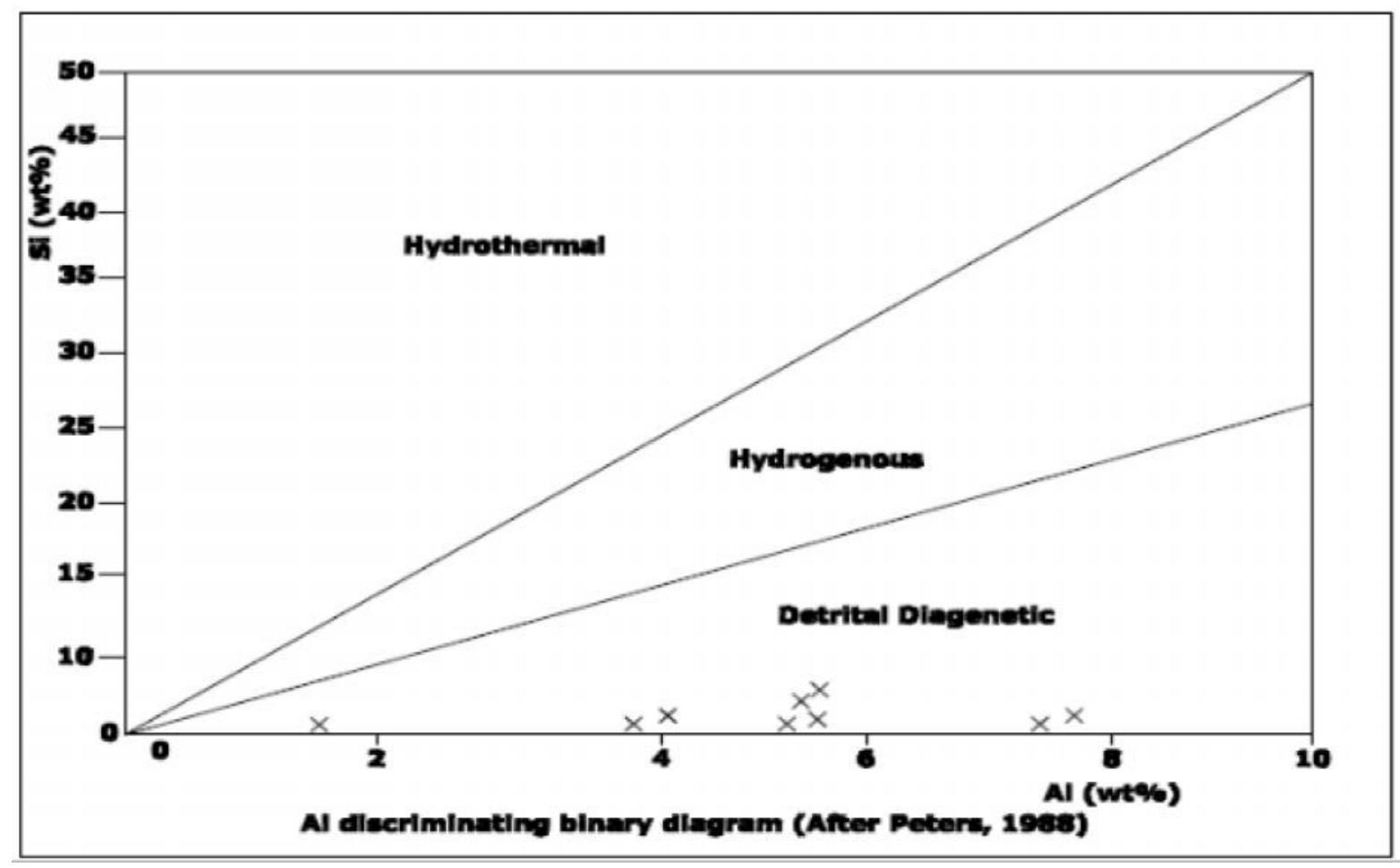

Fig. 12

\section{Conclusions}

- The geologic field investigation in the study area reveals that the Patti Formation ironstones consist of laminated fossiliferous ironstone facies, flattened spheroidal concretionary ironstone facies, and bioturbated ironstone facies.

- Petrography and XRD result shows the dominance of siderite, quartz, $\mathrm{k}$ aolinite, chlorite and hematite in the analyzed ironstones. These show that kaolinite thought to be the primary clay mineral had been largely replaced at early stage of diagenesis by siderite under reducing condition and low Eh

- Geochemical proxies suggest the precursors are deposited in normal seas but with influence of fresh water.

- We conclude that the ironstones are sideritic and diagenetic

\section{Acknowledgements}

We acknowledge the financial support of the Federal University Oye-Ekiti and TETFUND, Nigeria for the first author for the attendance of this conference (GSA 2016 Meeting). 
